\title{
THE ROLE OF MISSION ORIENTATION IN SUSTAINABLE BUSINESS EDUCATION
}

STEPHEN MORRIS

(corresponding author)

University of San Francisco

San Francisco, California, U.S.A.

morriss@usfca.edu

\section{ERIN GROGAN}

University of San Francisco

San Francisco, California, U.S.A.

egrogan@usfca.edu

Abstract. Many business schools embrace a mission or purpose to develop leaders with a focus on values and principles. In this article, we discuss the role of the institutional mission in teaching sustainability within a business school, and illustrate how mission can be adopted as a framework for discussing and operationalizing sustainability. Specifically, we provide examples of how to adopt mission orientation within a core business course in order to achieve a deeper awareness of sustainability issues and how a single business decision can impact many stakeholders. Moreover, while several of the pedagogical methods presented draw from Jesuit tradition, the strategies discussed can be applied within secular institutions. This article describes how this framework was used to encourage students to make sound and conscientious decisions in a business setting. In addition, we suggest methods for navigating obstacles in integrating mission orientation into undergraduate and graduate level courses. 
Keywords: mission orientation; sustainability; Ignatian Pedagogical Paradigm

\section{INTRODUCTION}

Institutions of higher education share common missions of research, teaching, and service in varying degrees. Service is often manifested as an expression of an institution's core values as it works to improve society at the local and global levels. The mission or purpose of an organization, when institutionalized, reinforced, and rewarded, can thus be a powerful motivation for individual and organizational behavior. The purpose of this article, therefore, is to explore how to incorporate an institution's mission and values into business education.

Several studies on how to integrate the concepts of sustainability into core courses in business education have been conducted (Benn \& Dunphy, 2009; Porter \& Cordoba, 2009; Rands, 2009; Rusinko, 2010). However, the necessary and integral components of mission and values for sustainable business education have not often been systematically incorporated into curricula in a way that leverages use of the mission to deepen the awareness and understanding of sustainability in business education.

Similar efforts have been made in incorporating value education into scientific education. The Vrije Universiteit of Amsterdam, based on the institution's historical and cultural concepts of Bildung or "whole person" education, has incorporated sustainable development and ethical reflection into the science and technology curricula, finding that students need more insight into moral values as distinct from empirical facts, methodological norms, and international conventions (Muijen, 2004). Education for sustainable development can also develop values clarification and mind-set shifts as a result of this targeted training when it is offered to undergraduate students of various disciplines on an extracurricular voluntary basis (Murry, Goodhew, \& Murry, 2014).

By their very nature, businesses must learn how to be sustainable and ongoing, or they cease to exist. This is evidenced by sustainability strategies used by businesses that are primarily driven by economics. Surveys indicate that companies which support sustainability projects in their organizations see sustainability as a revenue driver and expect green initiatives to confer a competitive advantage (Unruh \& Ettenson, 2010). However, if business education is to promote global sustainability awareness from a mission and values perspective, the corporate value 
system should address environmental and social concerns as a primary focus, with positive economic benefits as a secondary emphasis. We thus believe that making moral and social responsibility central to a student's educational foundation is necessary to replace the current fashion of using sustainability as a driver of economics. The concept of sustainability needs to be broadened to include social justice and environmental concerns. In contrast to studies conducted in other disciplines, sustainability education for future business leaders thus presents a more compelling need as these individuals may influence public policy, lead large commercial enterprises, or drive non-profit think tanks which help shape public opinion on social norms.

\section{LITERATURE}

Much has been written about the mission of business school education and its role in the preparation of students as future business leaders. The mission is the purpose for which an organization is created (Scott, Jaffe, \& Tobe, 1993). With regard to the Jesuit business educational mission, Andre Delbecq, former dean at the Leavey School of Business at Santa Clara University, framed it as one which focuses on moral and social perspectives, avoiding a singular focus on business profits (Delbecq, Cavanagh, Haughey, Hendrickson, Stebbins, \& Winkler, 2010). Similar to the German concept of Bildung, Cura Personalis-"care of the whole person"-is a tenet of Jesuit education. Within a Jesuit business educational context, therefore, Principe and Eisenhauer (2012) have suggested that mission be infused into a single core business course such as economics to systematize mission as a normative frame. In fact, with the increase in evidence of unethical business practices, many business schools have added a mandatory ethics course to satisfy the requirement of their social mission (Browning, 2009; Stark, 1993) As a result, sustainability, sometimes synonymous with ethical business practices, is put at the forefront of community concerns.

Petriglieri (2012) writes that it may once have been enough for business schools to train students' minds and hands while other institutions, such as local communities and long-term employers, took care of hearts and souls. This division of skill development and community concern is disappearing, however, due to the nomadic nature of professionals who have looser ties with local communities and employers (Petriglieri, 2012).

H. James Williams, dean of the Seidman College of Business, describes the growing concerns over the unethical behavior of businesses, concerns that have become more pronounced as smaller and more transpar- 
ent locally-owned business entities give way to publicly-held institutions that are larger, less transparent, and arguably less community-responsive. He advises business schools to create learning environments that provide opportunities for students to learn about ethics (including their philosophical underpinnings) and to practice exercising moral values in complex, real-world contexts (Williams, 2011).

In designing a framework to address sustainability issues, we reviewed the Jesuit tradition from which our institution's mission was drawn. The Ignatian Pedagogical Paradigm (IPP), a work commissioned by the Apostolate of Jesuit Education, calls for an approach to value learning and growth within the existing curricula (Van Hise \& Massey, 2010). The IPP describes the Jesuit educational goal as one that develops learners to habitually think and act with competence, conscience, and compassion, always seeking the greater good. A practical approach to applying the IPP uses the following steps: creating the conditions, laying the foundations, and providing the opportunities for the continual interplay of the student's experience, reflection, and action to occur (Korth, 1993).

\section{HYPOTHESIS}

Our hypothesis is that the adoption of a mission-oriented framework that draws from pedagogical approaches consistent with Jesuit traditions can create more diverse student learning outcomes and a stronger student engagement with, and awareness of, sustainability.

This article will therefore address what it means to have a mission orientation (criteria), how that criteria can best be applied to sustainability issues in business education, and whether mission orientation can be applied to other foundational business courses. We present several strategies for introducing a mission-oriented framework into an Operations Management course, and address some of the challenges facing business schools with a distinct social or ethical mission. We begin to address the issues that arise when key stakeholders lack interest in the integration of mission into curricula, as well as the issue of Jesuit business schools that do not embrace distinctly Ignatian pedagogies.

This article is organized as follows: Part I presents the methodology of the study, followed by a description of pedagogical strategies used within a business course. The framework examines the relationships between the elements of sustainability, and concepts and implementation of sustainability are discussed. In Part II, the results containing the 
student learning outcomes are displayed. Limitations, risks, and challenges are mentioned in Part III. Part IV is the conclusion, which identifies opportunities for mission orientation into other disciplines outside of operations courses.

\section{METHODOLOGY}

Orientation refers to the lens and perspective through which individuals participate, observe, relate, and impact others, whether voluntarily or involuntarily. If orientation is the perspective or angle, then mission orientation is the sharpening of focus within a specific contextual framework. In this article, the institutional mission of Jesuit business education will be used as a framework. However, other institutional missions regardless of faith can also be applied if these institutions articulate a values-based education. Private and public institutions are included regardless of tradition as long as they also serve a social justice missionthose who seek to serve others, venture into areas of discovery to achieve a greater good, or care for the world's most vulnerable.

When learning sustainability concepts, students must understand that businesses are part of a much larger system involving multiple stakeholders. Decision-making requires a perspective that incorporates social, economic, and environmental dimensions with the understanding of how others can be impacted in intentional and unintentional ways. Due to the complexity of most business interactions, however, several pedagogical methods from the Jesuit tradition, each reflective of the Ignatian Pedagogical Paradigm (IPP), can be applied as a framework to create context as well as evaluate and understand sustainability issues from a mission orientation (Rimanoczy, 2014). The model consists of dialogue and contemplation, service, discernment, reflection, and grace as means of transformational learning.

- Dialogue and contemplation means including and collaborating with others, inviting them regardless of their faith into conversation to work together and respect human values. It means appreciating diverse ideas while also working to achieve a shared vision. This can be applied by creating openness for contextual learning and application without predetermined biases.

- $\quad$ Service emphasizes action in serving others, and is shown more in deeds rather than words. It means creating transformational opportunities to form and strengthen the 
development of women and men for others. It also shifts focus from internal stakeholders to external ones.

- Discernment means seeking to see reality in the light of institutional values, understand the current situation, and quest with purposeful action. As applied to organizations, it means understanding the increasing disparity between rich and poor, the decline of workplace ethics, and the traditional support/incentives for individual success and achievement.

- $\quad$ Reflection should be done not only on our actions but on what we can learn from them as well. It means using past experience as a lesson in order to move forward in personal growth. It involves exercises that allow individuals to demonstrate the application of knowledge to address societal needs. It means understanding the individual's role and personal accountability in business operations.

- Grace is perhaps the most difficult lesson for instructors/ facilitators as it reduces their action or role, providing for individual discovery through mistakes as well as space for personal growth and discovery by allowing individuals to struggle with business challenges in a safe and nurturing environment.

\section{Sustainability Modalities}

The framework for mission orientation was selected for sustainability and corporate social responsibility education because the application of this framework reinforces an awareness of sustainability issues in numerous ways. Sustainability has been broadly described as the capacity to endure, and is often categorized under environmental, economic, and social dimensions.

- $\quad$ The environment/ecology dimension refers to the preservation of the environment and habitats, understanding impacts of waste disposal, reducing usage of the earth's resources, and minimizing impact on climate change.

- $\quad$ The economic dimension refers to the behavior and interactions of individuals and organizations and their role in the processes of production, consumption, and distribution of goods. 
- $\quad$ The social justice dimension refers to understanding offshored labor practices, differences in production standards, and the recognition of diverse parties with an emphasis on equitability as it relates to people.

In the past, sustainability had roots in environmental initiatives which were sometimes referred to as green initiatives. Most widely applied to building standards today, green initiatives have gained popularity with organizations in areas such as waste disposal, consumption patterns, and sourcing, which are then reinforced by positive economic benefits, thus affirming business decisions made based on conventional capitalism.

In this article, we do not define sustainability merely as an organization's ability to endure; more broadly and more centrally, we refer to the urgent need for personal and institutional responsibility in contributing to the greater good, with care and attention given to the world's most vulnerable. Cardinal Peter Turkson, in a lecture at the London School of Economics, stated that attempts made to achieve financial gains for the few while ignoring the needs of very many "[are] no longer intelligent, productive or justifiable" (Turkson, 2014). Organizations have a responsibility for stewardship and responsible resource management, that is, the selection, harvesting, and transportation of raw materials; labor standards for safety, pay, and benefits; production standards for disposal of waste; safety of products; and contribution to the local economy. Business and civic leaders can and should engage businesses in the transition to more sustainable management.

The increasing globalization of businesses of every scale has also focused attention on labor practices and fair trade activity for which international standards are being developed. Where once offshored labor practices primarily affected multinational businesses, there often are indirect effects generated for almost every business by a global trade and supply chain. For instance, sugar purchased from a U.S. distributor may have been produced and refined in Brazil or India. In this example, purchasing sugar harvested in India for a U.S. distributor makes the consumer partially responsible for poor labor practices in the fields of India by creating a demand for the product which in turn supports those current practices. Issues such as these are interconnected and cannot be thought of as separate concerns. Responsible stewardship and sustainable practices are thus necessary to create a responsible, ongoing organization.

Stakeholders in sustainability also extend beyond an organization and its voluntary participants such as the suppliers of raw materials, 
power, and labor. The involuntary participants include the environment which may be stripped to supply materials, water which may be redirected to supply power, and the unemployable workforce which in many areas include women.

The centrality of an institution's mission and values can reverse the perspective by which we ordinarily see the world. Instead of acting solely out of self-interest or profit-motive, one can try to better understand someone else's point of view, balancing the need for establishing a business as an ongoing concern with the need to serve the public good. These two factors need not be at odds-an example of merging business practices with public welfare is The Stride Rite Corporation, a $\$ 500$ million-per-year manufacturer of children's shoes, whose mission is to design "longstanding, quasi-medical dedication to foot care." Stride Rite is able to serve its mission and cultivate profits through marketing and appealing shoe designs (Nash, 1990).

If individuals are cultivated to place humanity and care for all things as their primary focus, then sustainability, we believe, would be a natural outcome. The role of education is to expose individuals to higher cognitive abilities and to develop self-awareness of these more complex and dynamic issues, beyond the functional and procedural knowledge of business.

\section{Curriculum Integration-Practical Application}

Laying a foundation for mission orientation begins with reviewing the institutional mission. The institutional mission is usually well-publicized and articulated on the organization's website. Business schools who receive accreditation, such as from the Association to Advance Collegiate Schools of Business (AACSB), are often required to articulate their mission and values (Cole, 2002). However, in the 2012 revision of the AACSB standards required for accreditation, institutions were also asked how they achieve their mission. Without specific guidelines, many institutions interpreted their mission in a variety of ways. For this reason, the first step in applying the mission oriented framework requires instructors to ask students to articulate their understanding of the mission and values of the business school, and how this compares with the university mission and values. Students are also required to research the missions of similar institutions to further analyze and provide their perspective of the similarities and differences among them. In addition, they should be asked to provide specific examples of activities that demonstrate how this was achieved, share their findings and observations with their group, and reflect upon how their personal perspectives may have or have not changed. 
Laying a mission awareness foundation is a critical and necessary step for introducing the relationship of mission to sustainability. Figure 1 shows the link between the mission and values of an institution and sustainability topics.

\begin{tabular}{|c|c|c|c|}
\hline & \multicolumn{3}{|c|}{$\begin{array}{l}\text { Mission and Values } \\
\text { Education of the whole person for the common good. }\end{array}$} \\
\hline & Environment & Economic & Social Justice \\
\hline $\begin{array}{l}\text { Sustainability } \\
\text { Modalities }\end{array}$ & $\begin{array}{l}\text { Preserving the environment, } \\
\text { reducing use of the earth's } \\
\text { resources, minimizing impact of } \\
\text { climate change, understanding } \\
\text { impact of waste disposal. }\end{array}$ & $\begin{array}{l}\text { Understanding consumption } \\
\text { patterns, analyzing } \\
\text { redistribution of wealth, } \\
\text { analyzing distribution } \\
\text { of goods. }\end{array}$ & $\begin{array}{c}\text { Recognizing diverse } \\
\text { stakeholders, } \\
\text { understanding differences } \\
\text { in labor standards. }\end{array}$ \\
\hline $\begin{array}{l}\text { Dialogue and } \\
\text { Contemplation }\end{array}$ & $\begin{array}{l}\text { Reconcile one's own ideas with } \\
\text { disparate ideas to understand the } \\
\text { ecological impact of decisions. }\end{array}$ & $\begin{array}{c}\text { Collaborating with other } \\
\text { stakeholders to equitably } \\
\text { distribute limited resources. }\end{array}$ & \begin{tabular}{|c|} 
Build and sustain \\
productive relationships \\
with customers, suppliers, \\
community members, etc.
\end{tabular} \\
\hline Service & $\begin{array}{l}\text { Decisions that benefit the } \\
\text { business' surroundings. }\end{array}$ & $\begin{array}{l}\text { Creating opportunities for } \\
\text { individuals to modify their } \\
\text { consumption behavior. }\end{array}$ & $\begin{array}{l}\text { Showing concern for } \\
\text { issues that transcend } \\
\text { one's own interest. }\end{array}$ \\
\hline Discernment & $\begin{array}{c}\text { Seeking to understand the multi- } \\
\text { faceted impact of decisions on the } \\
\text { environment for both short and } \\
\text { long-term effects. }\end{array}$ & $\begin{array}{c}\text { Questing to find subtleties in } \\
\text { how economic success } \\
\text { or stagnancy affects } \\
\text { communities. }\end{array}$ & $\begin{array}{l}\text { Finding an awareness of } \\
\text { similarity and } \\
\text { differences across } \\
\text { cultural groups. }\end{array}$ \\
\hline Reflection & $\begin{array}{l}\text { Using past experiences } \\
\text { to address societal needs. }\end{array}$ & $\begin{array}{l}\text { Determining if actions were } \\
\text { in line with institutional } \\
\text { mission and values. }\end{array}$ & $\begin{array}{c}\text { Suspending judgement } \\
\text { while gathering evidence } \\
\text { and evaluating personal } \\
\text { integrity. }\end{array}$ \\
\hline Grace & $\begin{array}{l}\text { Cultivating intellectual curiosity as } \\
\text { it relates to the environment. }\end{array}$ & $\begin{array}{l}\text { Allowing to learn from } \\
\text { reflections and provide } \\
\text { reasonable responses to } \\
\text { improvements identified. }\end{array}$ & $\begin{array}{l}\text { Moving forward from } \\
\text { identified issues and } \\
\text { maintaining } \\
\text { commitment to others. }\end{array}$ \\
\hline
\end{tabular}

Figure 1: Link between the mission and values of an institution and sustainability topics.

Using the Ignatian pedagogical model, we encourage discussion, interpretation, and demonstration of mission-oriented action: What are examples of institutional initiatives that have been driven by the mission? How do our personal actions reflect or contradict the mission? Students are asked to critique and construct arguments, synthesize their 
ideas, and use this exercise to solve problems. They are challenged both to reconcile disparate ideas and show concern for the common good.

We introduced many of these concepts into one section of a required undergraduate business course that taught operations management and supply chain principles. Students in other sections of the course were presented with lectures, case studies, and simulations without the mission orientation. In the pilot section, the students were tasked with creating several businesses while immersed in an experiential learning environment, and were expected to learn the mission-oriented framework.

The impact of sustainability decisions should not be viewed simply as right or wrong as is often the case with simulations; they should be seen as a progressive improvement along a spectrum toward achieving a more sustainable solution. Moreover, choices toward sustainability within an organization are associated with tradeoffs, and part of sustainability education is to create a greater understanding of how various stakeholders are affected. Based on this complexity, we explored various pedagogical approaches which, through increased engagement, may be able to help students better achieve a deeper understanding of sustainability issues in a business environment.

Establishing the knowledge of the various components of the mission early in the semester is necessary for establishing a foundation on which to apply mission-driven goals within an operations course context. Thus, after exposing the students to literature and other materials about mission and values, the concept of sustainability in business was introduced. In order to create context conducive to personal discovery, students were assigned to groups and asked to create several small businesses, each running for three to four weeks. Several groups decided to maintain their original business ideas and expanded and/or refined them in subsequent modules.

Group formation allowed for collaboration with others from diverse backgrounds, and the creation of their own businesses allowed the students to actively participate in decision-making in various functions while rotating roles through different phases of their business. Using the mission-oriented framework, the students were tasked with addressing the following issues and questions:

- Dialogue and Contemplation. The students were asked individually to think about and then discuss in their groups how external stakeholders were engaged. What do they consider to be a fair cost or price? Specifically, we asked for 
the group's reasoning that underlay this determination. For instance, how did they balance the desire to set a high price with what they considered to be a fair price?

- $\quad$ Service. Does their product or service contribute to society or target an underserved population? What demographic has been served? How did they select the market in which to operate? Why? How did customers like the product or service and what mechanisms were used to gather this information? Were customers' needs met and did the product or service contribute to their well-being? For example, did the students agree with the removal of trans fats even though it increased the cost of certain foods? How do the questions and answers link back to the mission?

- $\quad$ Discernment. What societal impacts have been made? We discussed TOMS Shoes, LLC (http://www.toms.com) and their One for One mission. Not only does this organization serve underserved communities with critical supplies of shoes, but local labor is used in manufacturing the product and the raw material is sustainable. In a similar vein, we asked the students in which ways their goods or services may be sustainable and if they made an impact on the common good. How can you measure this impact? What are the implications of your choices? What are the effects of your sourcing decisions on your suppliers and their practices? The students use applications of real cases to discern these dimensions of moral reasoning and articulate the role mission has played in their decisions.

- Reflection. After completing a business cycle, we asked how the students balanced economic, environmental, and social justice issues. How did the mission guide your choices? If not, why not? This is a critical part of the curricula as students have often expressed deeper awareness of how they could have used the mission to better scrutinize their choices. During this exercise, the students can learn how they could have made more sustainable choices, such as with regard to packaging used for their products, raw materials used to construct their products, or pricing methods that may have been more equitable among their customer base.

- Grace. What lessons learned from the project could be applied to future projects? How did their team work to- 
gether to share the responsibilities and the discoveries in their project?

These and similar questions serve as a guide for discourse and learning which can in turn serve as a basis for both formal and informal learning. Further conversation can be centered on specific functional areas in the business cycle. For instance, how does a mission orientation affect choices in sales and marketing strategy, product creation (prototyping, manufacturing, raw materials), sourcing in the supply chain (locally or globally), shipping and packaging, waste byproducts such as carbon footprint, and financial cost implications?

Several opportunities to apply mission orientation were provided by dividing the curriculum into three projects within the semester. We believe that such continuous active participation reinforces a student's ability to apply sustainability strategies that can be adapted for various conditions. Since each project was distinct, the students often encountered new issues and were forced to re-engage with the pedagogical model using flexible and responsive solutions that resulted from the reflection and grace gained from prior projects. The re-engagement occurred even with those groups who decided to stay with their original product or service. Several times during the semester, the students were also asked about how incorporating sustainable practices into their business was linked to mission and how various stakeholders were affected. We challenged the students to consider whether a product or service must be sustainable, inherently contribute to society, or whether it was sufficient for their business to dedicate proceeds to charitable contributions for their organization to be described as sustainable or socially responsible. We asked them to reflect upon what intentions, beliefs, and biases they had toward sustainability and how their ideas may have been changed or reinforced.

\section{Assessment}

Assessment of mission orientation can be challenging. How can one be sure that mission orientation has been achieved and how can we evaluate the impact mission orientation has had on making sustainable choices? Since the mission orientation concepts were introduced prior to the concept of sustainability and corporate social responsibility, we attempted to establish mission and path dependence as the causal factors for change. Path dependence explains how one can make a decision based on examples and situations one has encountered in the past and the reasons for making decisions then. It also points to observations the students made after reflecting upon whether they had made the best decision that they could, given the information they had at the time. For 
example, the students may have chosen to purchase raw materials from a local store in an attempt to support community businesses, only to learn later on that the store pollutes the local water supply by dumping wastes into the local stream.

While we believe, based on social justice, that a mission-oriented action must always be sustainable, the reverse is not always true. Actions can be sustainable but not mission-oriented in that some gain at the expense of others. Based on this premise, we developed a rubric for the course to assess how well the student projects incorporated sustainability and the outcomes that resulted. The assessment included:

- Dialogue and Contemplation. How well did the students communicate, organize, reason, and plan? In an environment where there is no single right answer, how did their joint problem solving manifest in their business decisions? Business plans, participation in discussion, and group cooperation were evaluated. In addition, a peer assessment tool was used to evaluate the group dynamic versus individual participation.

- $\quad$ Service. Projects were assessed partially on whether or not their products or services had a societal benefit, and on how well the students understood the effects of their projects on various stakeholders. Did the students shift their natural tendencies for an internal focus in assessing their own organizations to one that estimated and measured the impact of their decisions on others? Were trade-offs discussed and assessed?

- Discernment. Within the context of their business projects, the groups were asked about direct versus indirect effects on environment, whether they were aware of cultural influences, and whether any of their decisions had a financial or operational impact. They were also asked to develop their own set of assessment criteria for each of their projects which included assessing the management of supply chains, operational obstacles encountered, and how these were overcome. Within these projects and their write-ups, the students were tasked with integrating the elements of business operations in the distinct light of mission orientation.

- Reflection. For their final reflections, the students were asked to submit answers to at least one of the following 
questions: What operational strategies did your team use? How were your operations influenced by your understanding of sustainability? How were your supply chains affected by your choice of supplier? After the groups submitted their reflections, the students also had the opportunity to re-submit their papers based on additional personal observations.

- $\quad$ Grace. The students were asked to communicate what lessons were learned, why these were meaningful, and how these discoveries could influence future projects and work that they may have.

In addition to assessing the students on the various aspects of the framework, we asked them questions during the semester concerning how well they operated their businesses or projects and to what degree their experiences and outcomes informed their judgment.

For example, one exercise asked the students to "elaborate on each of the obstacles your team encountered and how your team responded to each of these challenges." Here the emphasis was not on what the "right" operational procedure might be, but on the gradual realization that there may be more than one solution. The team needed to identify the challenges and prioritize the order in which they addressed them, taking into account the impact on various stakeholders. At every pivotal point in their projects, they were tasked to use the mission to guide them. Thus, in their self-assessments and because of mission orientation, the students often described a shift in their frame of reference-from their own self-interest or profit-driven sensibilities to other important organizational and societal needs such as teamwork, societal contribution, waste reduction, and carbon footprint management.

\section{RESULTS}

Within an institution where learning is characterized as a humanizing social activity, mission orientation can and should be emphasized for achieving student learning outcomes in teaching sustainability. Though challenging, the goal is to enable individuals to cope with complex situations, to act in a reasonable manner after reflection, and to make decisions in a dynamic environment with budgetary constraints and limited timeframes.

One student group created a greeting card business which continues to sell on Etsy. Made with recycled paper and designed so that a maxi- 
mum number of cards could be printed on a single sheet of paper with minimal waste, the creative designs are popular with a younger set for whom paper cards are considered a novelty over conventional texting, tweets, and other forms of social media communication. In an environment where going paperless is emphasized, we asked how the mission had affected their decision to create this business and how their business made sustainable decisions. In articulating their response, the group explained that the origin of this idea came from the mission's call for a more interconnected and compassionate individual. The group thus found, in their survey of other undergraduate students and friends, that written communication is considered more personal, and takes more of an effort over the ease and brevity of electronic communication.

Another student group created a project where they sold a traditional Latin treat known as mango con chile-fresh cut mangoes with a hot and tangy Mexican spice. The group did quite well but encountered an increase in the cost of mangoes after only two sales cycles. After speaking with the supplier, a local grocer, they learned that the price of mangoes increased after the grocer's cost had increased, and that this was related to a bad crop in Mexico. The students had many observations which came out of this project, including the fact that their small project had global reach, how they had to allocate the division of labor between each of the group members to ensure fairness, and thinking about how their project could contribute to society. One of the reasons they came up with this idea was to create a project that not only tasted good but would be nutritious for other students who comprised their customer base.

Within a mission framework, the students were shown to actively participate, and collaboratively apply sustainability strategies that were responsive to the changing business landscapes. They also began to understand the impact their decisions might have on multiple stakeholders. Mission orientation was also evident in their observations and reflections, samples of which are provided below.

An organization has to think about what influence their decisions can have [on] other organizations and [on] society. In order to become more socially responsible, an organization has to think about their products' impact on the environment, social culture, social standard [...] etc.

I do feel more aware of global supply chain issues and how [these] can affect a business. This influences [me to try] to find different suppliers for my business and not [...] stick with just one supplier.

An organization can be more socially responsible by having products that are accepted by different communities and trying to help those commu- 
nities. The factors a business should be concerned with are that if the business has any complications with the community and if their products are harmful.

Organization(s) could become more socially responsible, as long as they ... reflect (on) their performance that gives back to the public [sic]. For example, a company could donate part of [their] profits to a non-profit organization.

I think [...] paying attention to the carbon emissions that will affect [...] people around the world. Businesses should be concerned with the people, planet, and profit because those are the most important things to think about. You have to make money yet businesses should pay attention to the people and planet and be sustainable as a business.

By considering not only their best interests [...] but also the people/ public[s] that their business will have an impact on. A few of the things that a business should definitely be concerned about is [...] environment[al] sustainability.

All organizations should assume some social responsibility, not just because it is the right thing to do, but [because] it improves the public image of your brand which will in turn make you more successful.

We believe that by providing them with relatable opportunities to practice mission orientation, students are able to internalize complex cognitive trade-offs associated with sustainable strategies. For instance, real life scenarios in which students must negotiate with multiple suppliers requires an understanding of their financial limitations while strengthening their communications skills and emotional intelligence. As shown in their discussions, actions, and written conclusions, this integrated learning approach within the mission-oriented framework enhances the ability to practice competencies such as systems thinking and communications skills in complex situations.

As students create their own contexts for learning, it is important for instructors to remember not to trivialize students' attempts to practice mission-oriented strategies. For instance, trying to become equitable and compassionate in the negotiation of prices for mangoes helps students practice the internalization of mission in their actions, even though the impact can be limited-it is unlikely that undergraduate students will have the ability to control decisions that have large scale impact on human rights. However, the more opportunities students have to apply the mission and values, the more quickly mission orientation will be internalized as their norm. 
As the business landscape shifts in response to drivers such as technological change, globalization, regulation, and environmental concerns, the inculcation of mission orientation will provide individuals a framework for navigating through such changes. Students, working from the orientation of mission, will be able to align practices, policies, and decision-making in order to achieve organizational mission despite the changing business environment. Incorporating a mission orientation approach to content delivery can also be a powerful way of engaging faculty to expand their views of the institutional mission and understand their part in developing social and moral business leaders for the future.

\section{CHALLENGES \& RISKS}

A mission-oriented framework takes time to be introduced to students and a commitment must be made to infuse this throughout the curriculum. Offering opportunities to practice the application of the Ignatian framework, as well as providing adequate feedback and time for additional conversation around the use of the framework in sustainable business, is a necessary part of deepening the understanding of sustainability issues. Sometimes the business challenges encountered do not have a clear solution. There may be more than one path to several possible solutions, each with varying degrees of risks and trade-offs. Students learn that some decisions involve uncertainty, and they struggle with the process of discernment. This may be challenging for those who have been accustomed to being provided with one right answer. In the end, having a foundation in Ignatian values and a framework should help the student make more sustainable business decisions.

In addition to Operations Management, this framework can be applied to other foundational courses in business education. For instance, when the students applied this to the marketing aspect of creating their businesses or projects, they were asked, "Which markets does your product or service serve? What assumptions do you have for the targeted customer base?" This addresses the issue that many markets may not be served based on income levels or for political reasons, such as the conscious decision that many pharmaceutical companies have made to ignore diseases which occur in emerging economies. Similar opportunities for mission orientation could be provided in a finance course as well, with questions such as: "Were results calculated in a systematic way? Was fair representation made? How does one assess market risks in other countries?" These and other questions can serve as a base for 
deepening sustainability awareness as separate disciplines support different but integrated parts of an organization.

Grounding the students in sustainability requires considerable time and effort from the instructor/facilitator, as well as a commitment from individual learners. As one student stated, "I now know that there is no such thing as too much research when it comes to global supply chain[s], because anything and [everything] will go wrong (at least be prepared for that to be the case)." Individual learners become aware of their own contributions to learning and that social justice requires critical scrutiny.

However, an experiential, practical approach can only be adopted on a broader scale within business schools by offering support to faculty. Despite the fact that many faculty may be hired into a Jesuit institution, many may be unfamiliar with the IPP and/or Jesuit teaching traditions. In order to address this lack of understanding of the institution's mission, teaching development workshops can be designed for instructors to learn about the Jesuit teaching tradition, and faculty can learn how to apply various strategies. A faculty orientation can include an overview of the mission and instructors can be invited to discuss how to adopt IPP into their curricula. Other methods include faculty learning communities or offering to have peer learning or team teaching to allow more experienced facilitators to work with less experienced faculty in sharing their in-class discussion themes.

When faculty are invited to sit in classes where students discuss complex issues, such as the dilemma posed by the drought in California, how water is being rationed, and how farm lands are laying unused, they will learn more about the Ignatian process. If a dean wishes to adopt a mission-oriented approach but key faculty are resistant, he or she could clarify why the approach is important and provide incentives for integrating the mission into the curricula. If a junior faculty member wishes to teach mission-oriented sustainability but the chair is not supportive, the faculty may seek the support of an associate dean or the dean.

There are also challenges that business schools in universities with a distinct social mission face where there is a lack of mission integration into the curriculum among key stakeholders. Moreover, there are some Jesuit universities that face this conundrum of not having the mission known or integrated into the curriculum. For example, there may be academic leadership such as deans or associate deans who are not familiar with the mission or who are not interested in integrating the institution's mission into the curriculum. Department chairs and faculty may not feel it necessary as part of the nuts and bolts of business education or may feel that the institutional mission does not necessarily impact their 
work. Furthermore, there could be lack of support for mission orientation from an academic department's advisory board.

Finally, an additional risk is that the business environment will not support mission orientation; the students are, or will be, working with organizations that focus on market efficiency, profitability, and time to market, and these priorities will overshadow a mission orientation. Perhaps the mission and core values get pushed to secondary considerations. We thus tasked the students with asking how a mission orientation can be supported and cultivated beyond their own organization.

\section{CONCLUSION}

Without businesses, we would not be able to transform the world's resources into countless benefits. But businesses must foster invention and innovation while understanding the impact development has on the societies surrounding them and in which they operate. We believe that businesses must have the forethought to realize the implications of the needs and rights of future generations. A mission-oriented framework is thus a powerful way to open individuals to ways of thinking about sustainability in its broadest form. This framework can be an effective means of applying the critical thinking methods developed within the Jesuit tradition to help solve current and complex business problems. Moreover, the application of the framework and its resulting benefits are not exclusive to Jesuit business schools, for these can also be applied to those institutions with a social mission. This framework can accomplish the "respect for creation, the surrounding society, and the needs and rights of future generations" by increasing student engagement in sustainability education (Turkson, 2012).

Within an organizational setting, individuals can begin to realize their humanity and be cultivated to become intelligent, conscious, and responsible members of society with a deliberate call to action. This frame of reference, a mission and values orientation, will enable students to act with the knowledge that sustainability and social awareness are the responsibility of people in all areas of an organization, and that they are interdependent, linking internal departments to external environments. This development of moral reasoning in future business leaders will hopefully help drive organizational transition to bring about changes in areas such as human rights, climate change, and public policy.

Although sustainability concerns may fall in and out of fashion, academia must be the fertile ground in which to plant a mission orientation in business education to address ever-growing societal needs. We 
believe that business education should not only provide the fundamental skills and knowledge needed to be successful, but that institutions with a social mission must also educate students not only to know what to do but how to do it, and why they must do it. Educators can provide opportunities for students to develop an awareness of others as well as ethical conviction, take responsibility toward self and others, and demonstrate concern for others. By using a mission orientation framework, individuals can be tasked to understand their part in a larger and more complex multi-stakeholder world.

Though this study focused primarily on using a mission-oriented framework in an operations management course, such a framework can be infused into all the functional areas of business education, including management, human resources, finance, and product innovation. Reorienting for this perspective can provide a more holistic and integrative understanding of business and its role in society.

\section{REFERENCES}

Benn, S., \& Dunphy, D. 2009. Action research as an approach to integrating sustainability into MBA programs: An exploratory study. Journal of Management Education, 33(3): 276-295.

Browning, M. 2009. An analysis of values, mission and vision statements within AACSB accredited schools of business. ASBBS 16th Annual Conference and Proceedings. Las Vegas, NV.

Cole, G. 2002. Online mission statements: Briefly stated. www.FirstMonday.com.

Delbecq, A., Cavanagh, G., Haughey, J., Hendrickson, A., Stebbins, M., \& Winkler, A. 2010. Higher education for business in the Jesuit tradition. Journal of Jesuit Business Education, 1: 253-265.

Korth, S. 1993. Precis of Ignation pedagogy: A practical approach. A previously unpublished summary of the document developed by the International Center for Jesuit Education, 280-284.

Murry, P., Goodhew, J., \& Murry, S. 2014. The heart of ESD: Personally engaging learning with sustainability. Environmental Education Research, 20(5): 718.

Muijen, H. 2004. Integrating value education and sustainable development in a Dutch university curriculum. International Journal of Sustainability in Higher Education, 5(1): 21-32.

Nash, L. L. 1990. Good intentions aside: A manager's guide to resolving ethical problems. Harvard Business Press.

Petriglieri, G. 2012. Are business schools clueless or evil? Harvard Business Review Blog, Spring 2012.

Porter, T., \& Cordoba, J. 2009. Three views of systems theories and their implications for sustainability education. Journal of Management Education, 33(3): 323-347. 
Principe, K., \& Eisenhauer, J. 2012. Fulfilling our mission: Incorporating Catholic social teaching into the core business curriculum. Journal of Jesuit Business Education, 3: 156-162.

Rands, G. 2009. A principle-attribute matrix for sustainable management education and its applications: The case for change-oriented service-learning projects. Journal of Management Education, 33(3): 296-322.

Rimanoczy, I. 2014. A matter of being: Developing sustainability-minded leaders. Journal of Management for Global Sustainability, 2(1): 95-122.

Rusinko, C. 2010. Integrating sustainability in higher education: A generic matrix. International Journal of Sustainability in Higher Education, 11(3): 250-259.

Scott, S., Jaffe, D., \& Tobe, G. 1993. Organizational vision, values, and mission: Building the organizations of tomorrow. Thomson Crisp Learning.

Stark, A. 1993. What's the matter with business ethics? Harvard Business Review, 71(3): 38-40.

Turkson, P. 2012. Business as a vocation: Catholic social teaching and business education. Journal of Catholic Higher Education, 31(2): 151-167.

Turkson, P. 2014. Towards reforming the international financial and monetary systems. Lecture at London School of Economics. Pontificium Consilium De Iustitia et Pace.

Unruh, G., \& Ettenson, R. 2010. Growing green: Three smart paths to developing sustainable products. Harvard Business Review, June: 94-100.

Van Hise, J., \& Massey, D. 2010. Applying the Ignatian pedagogical paradigm to the creation of an accounting ethics course. Journal of Business Ethics, 96: 453-465.

Williams, H. J. 2011. Business school and business ethics: Responsibility and response. Seidman Business Review, 17(1): Article 9. 